\title{
Influence of the Month on the Chemical Composition of Mediterranean Italian Buffalo Milk
}

\author{
R. De Vivo, R. Napolano and L. Zicarelli \\ Dipartimento di Medicina Veterinaria e Produzioni Animali, Via Delpino 1, 80137 Napoli, Università Federico \\ II, Napoli, Italy
}

\begin{abstract}
It is known that the chemical composition of milk is influenced by several factors and the length of lactation plays a prominent role. In Italy, where the reproductive activity of the herd is aimed at the demand for milk from the market, the chemical composition is influenced not only by the adoption or otherwise by the out-breeding-mating-strategy (OBMS) but also by the severity which characterise these techniques (the length of the interruption of sexual promiscuity).

The productions and the chemical composition of the milk of 23 farms (average 9000 buffaloes a year) were processed from 2011 to August 2016. The milk was daily conferred and analysed. We evaluated the milk production $(\mathrm{kg})$, the percentage of fat, protein, lactose, dairy yield calculated with the equation of Altiero (1989), the values of the titratable acidity $\left({ }^{\circ} \mathrm{SH}\right)$ and of $\mathrm{pH}$. For each parameter, the monthly values of each farm were divided by the respective annual average and were expressed as an index (monthly values/annual average) in order to homogenize the graphical representations.
\end{abstract}

Keywords: Buffalo milk, dairy yield.

\section{INTRODUCTION}

It is known that the chemical composition of milk is influenced by several factors and the length of lactation plays a preeminent role [1-4]. In some species, such as buffalo $[5,6]$, presenting a seasonal reproductive activity, if the males are always present in the herd, the effect of lactation length is confused with that of the month of birth because most of the subjects gather births in a short period. In Italy, where the reproductive activity of the buffalo herd is aimed at the demand for milk from the market, in many farms is adopted [7] the out-breeding-mating-strategy (OBMS). In this case the chemical composition is influenced not only by the adoption or less of the out-breeding-mating-strategy (OBMS) but also by the severity which characterise this technique (length of the interruption of sexual promiscuity). It seemed interesting to investigate the influence of the month of the year on the chemical composition of milk in function of the adoption or less of the OBMS technique and/or the severity or less this technique is employed.

\section{MATERIALS AND METHODS}

The productions and the chemical composition of the milk of 23 farms (average 9000 buffaloes a year) were processed from 2011 to August 2016. The milk was daily conferred and analysed. We evaluated the

*Address correspondence to this author at the Dipartimento di Medicina Veterinaria e Produzioni Animali, Via Delpino 1, 80137 Napoli, Università Federico II, Napoli, Italy; Tel: 3338116 952; E-mail: robertodevivo@virgilio.it, roberto.devivo2@istruzione.it milk production $(\mathrm{kg})$, the percentage of fat, protein, lactose, dairy yield calculated with the equation of Intrieri et al. [8] or with the equation of Altiero et al. [9], the values of the titratable acidity $\left({ }^{\circ} \mathrm{SH}\right)$ and of $\mathrm{pH}$. For each parameter, the monthly values of each farm were divided by the respective annual average and were expressed as an index (monthly values/annual average) in order to homogenize the graphical representations. The farms were divided into three groups: group A, (winter production), characterized by a higher production between October to March, Group $B$ (continuous production), characterized by a more or less constant monthly production and $\mathrm{C}$ group characterized by a increased production in the spring summer (April to September). The groups A, B and C were made up of 8,4 and 11 farms respectively. For each parameter we reported the average trend for each group.

\section{RESULTS}

\section{Milk Production}

In Figures 1, 2, 3 and $\mathbf{4}$ we show the trend of the indexes (ratio) of milk production of the 23 farms (Figure 1) and of above classified farms with winter production (group A, Figure 2), with production tendentially constant (group B, Figure 3 ) or with OBMS production (group $C$, Figure 4) respectively. From the Figure 2, 3 and 4, it is easy understand because the farms were subdivided in the three groups. The farms of the group A (Figure 2) recorded low production of milk between April and June when the market requires 


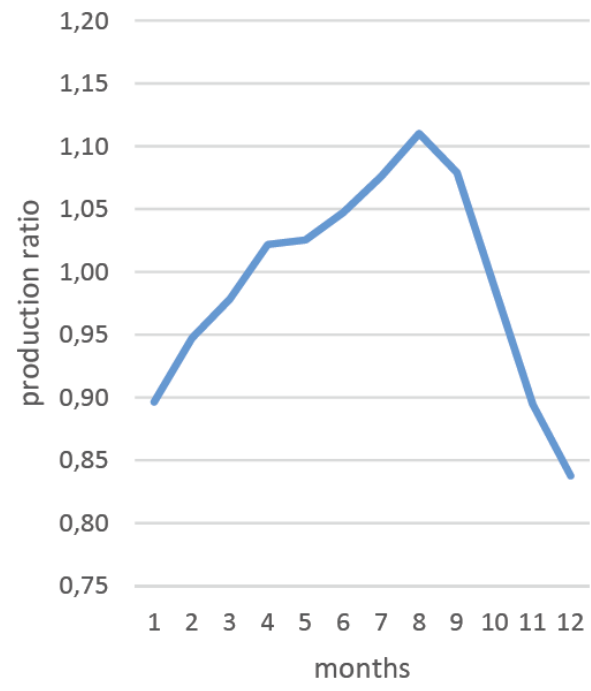

Figure 1: Milk production (total farms).

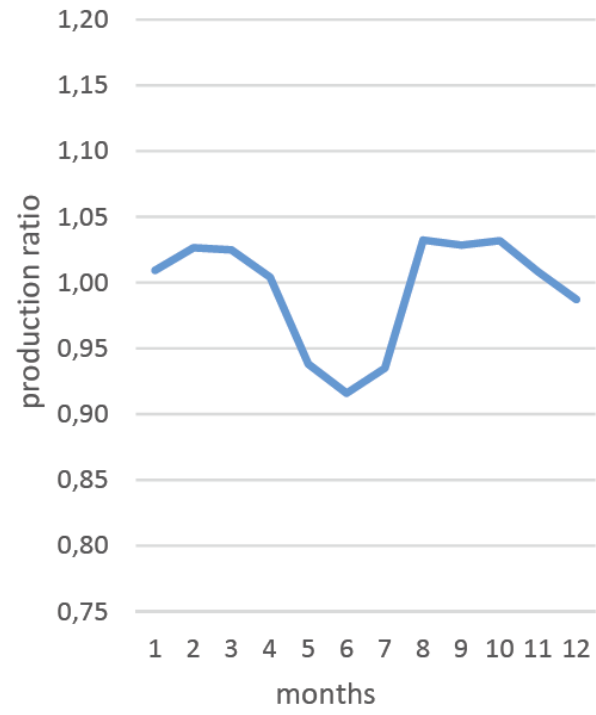

Figure 2: Winter production group A (8 farms).

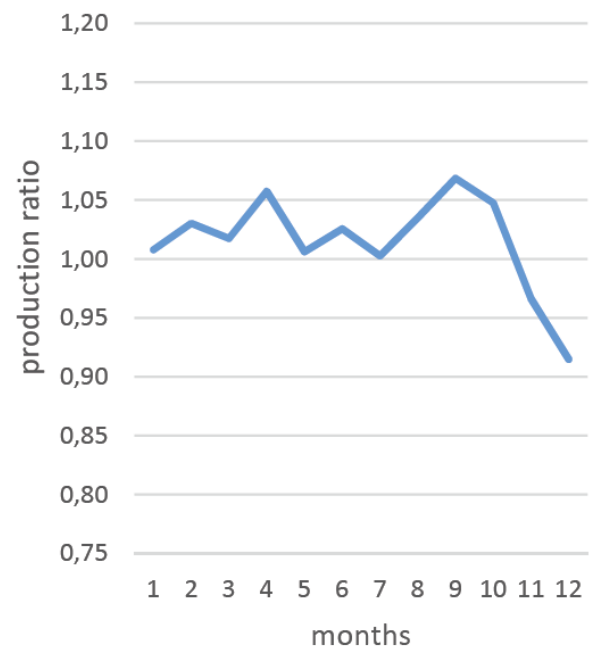

Figure 3: Costant production group B (4 farms).

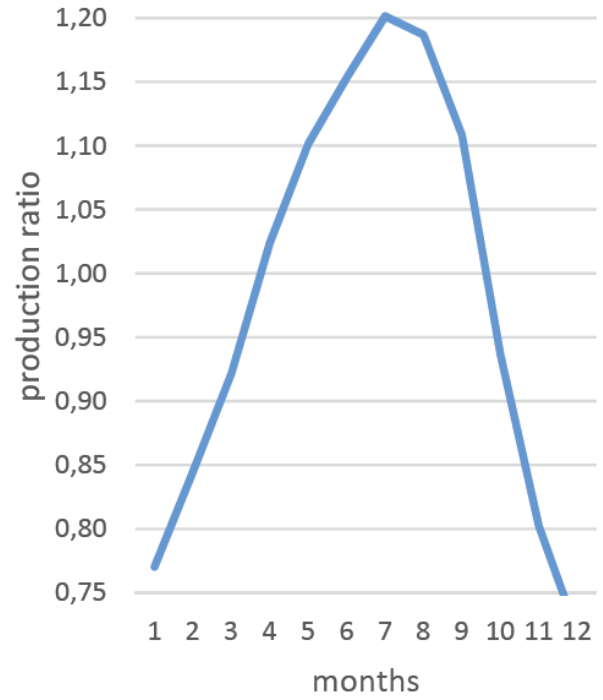

Figure 4: OBMS production group C (11 farms).

more milk. In Figure $\mathbf{3}$, there was a productive production tendentially constant (group B) from the month of January up to the month of August and a decrease between September and December. The farms of the group $\mathrm{C}$ confer in perfect synchrony with the request of market. It clear that at the DOP cheese manufactory of the trial the milk flows in sync with the market demand (Figure 1).

\section{Milk Lipid Percentage}

Figure 5 shows the trend of the lipid content recorded in the 23 farms on a monthly basis. The lipid percentage decreases from January to April, increases until November and decreases in December when the calving period starts. Between March and June the percentage of lipid of the farms of group $C$ (Figure 8 ) is

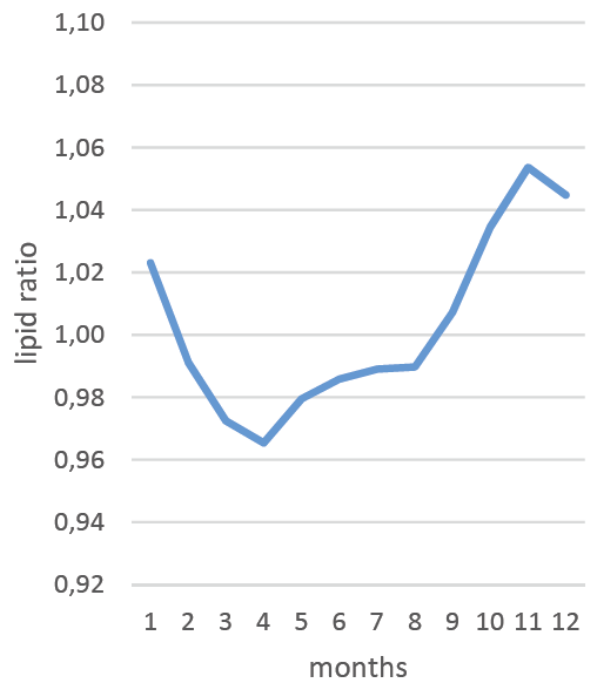

Figure 5: Lipid (total farms). 
the lowest, while is the highest between September and December and in January and February. Compared to the average value (Figure 5) the fat percentage of group C (Figure 8) is more similar because the number of the farms of $C$ group is higher. The trend of the lipid percentage in the other two groups ( $A$ and $B$ ) is similar to the average value only between September and November.

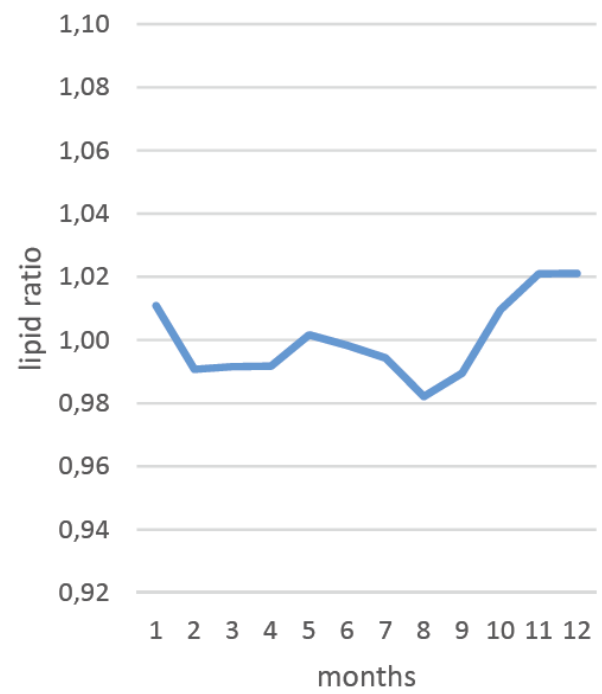

Figure 6: Lipid winter production, group A.

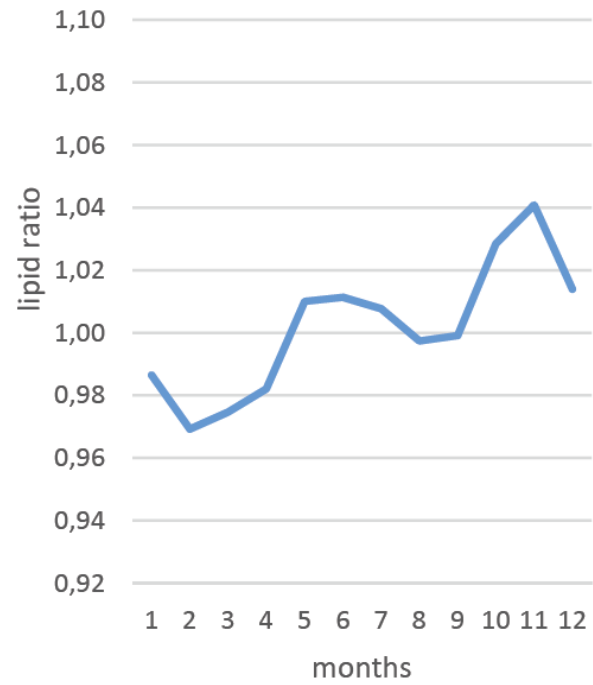

Figure 7: Lipid costant production, group B.

\section{Protein Percentage}

Figure 9 shows the trend of protein content recorded on a monthly basis. If we compare the pattern shown in Figure $\mathbf{9}$ with that one shown in Figure $\mathbf{5}$ there are some coincidences. It is known that between lipid and protein content there is a close association. The trend of protein percentage of group $C$ (Figure 12) is similar to the medium while the trend of protein percentage of the group $B$ is different from the average values (Figure 11). The trend of protein percentage of group A (Figure 10) is tendentially constant.

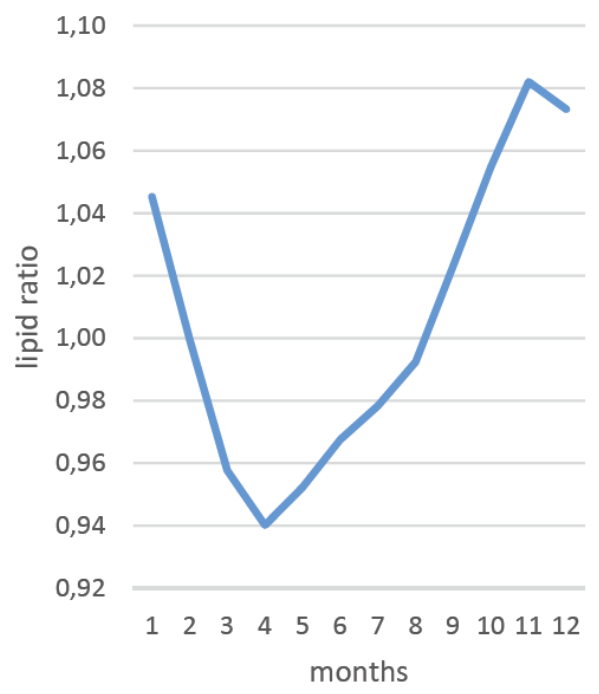

Figure 8: Lipid OBMS production, group C.

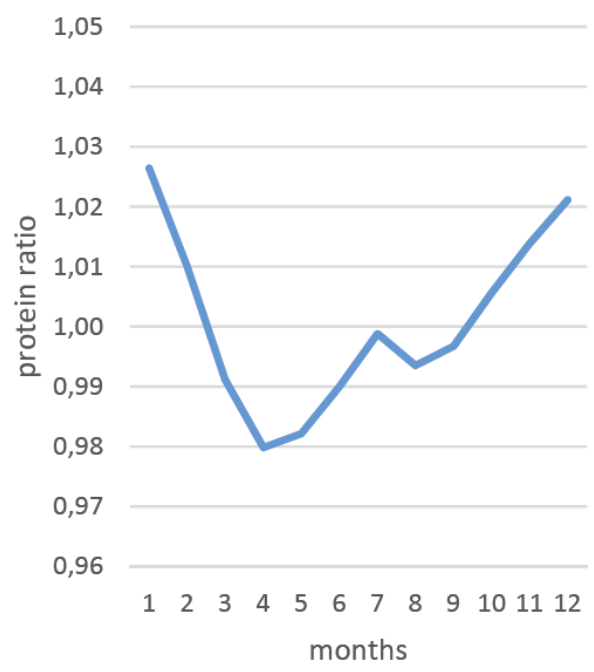

Figure 9: Proteins (total farms).

\section{Dairy Yield}

Between November and January of the following year, the 23 farms and particularly the group C (Figure 16) has the highest dairy yield while between April and July the lowest. The phenomenon depends on the higher calving number that occurs in this group between April and July and by poor calving incidence between November and January of the following year (Figure 16). Figures 14 (group A) and 15 (group B) show how the month influences the performance dairy less than in group $C$ (Figure 16). 


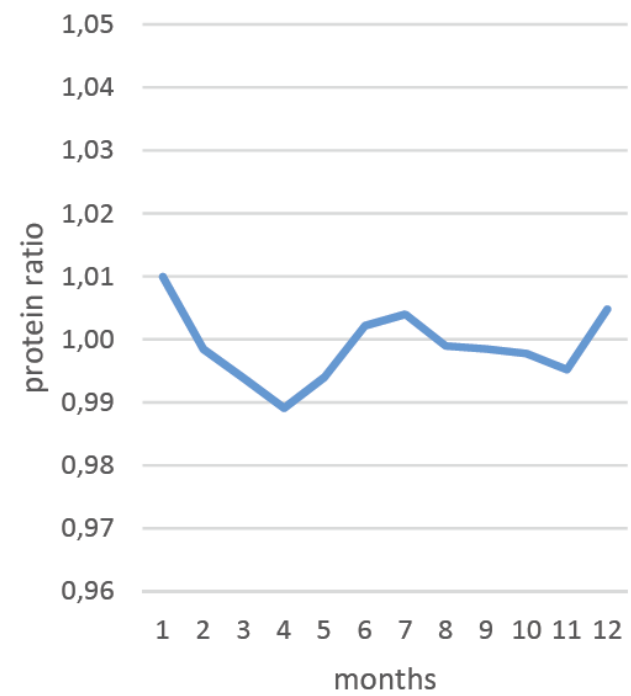

Figure 10: Protein winter production, group A.

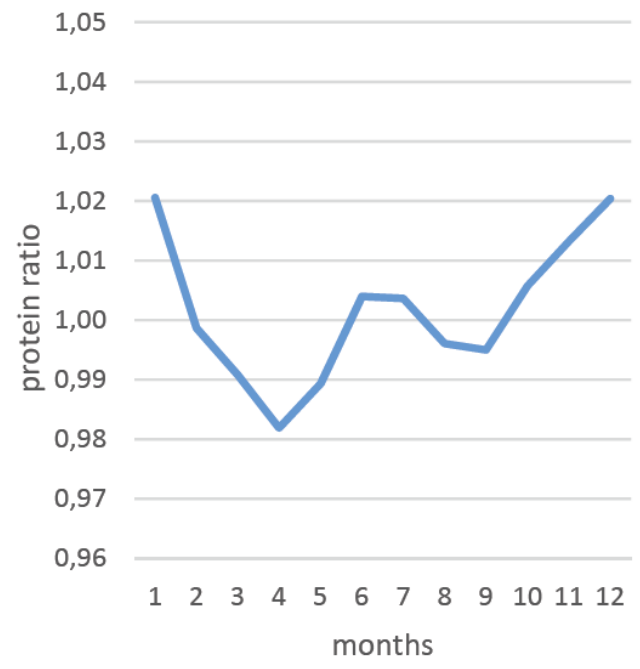

Figure 11: Protein costant production, group B.

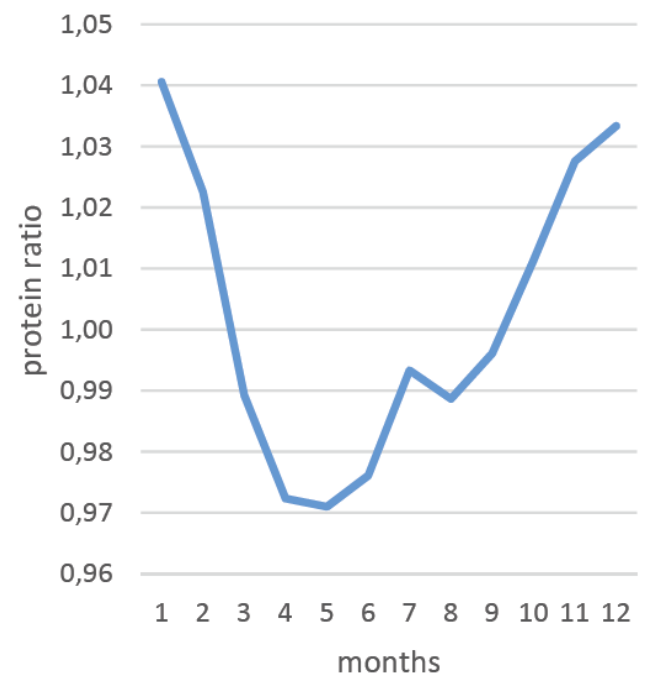

Figure 12: Protein OBMS production, group $\mathrm{C}$.

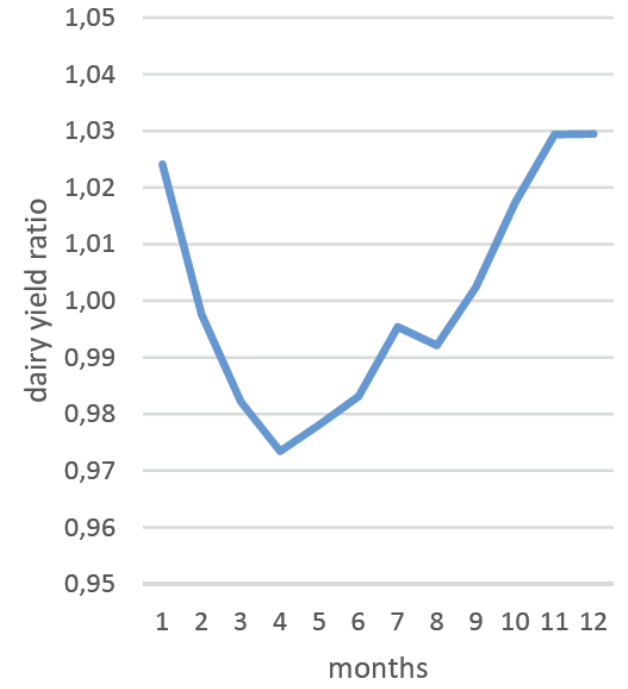

Figure 13: Dairy yield (total farms).

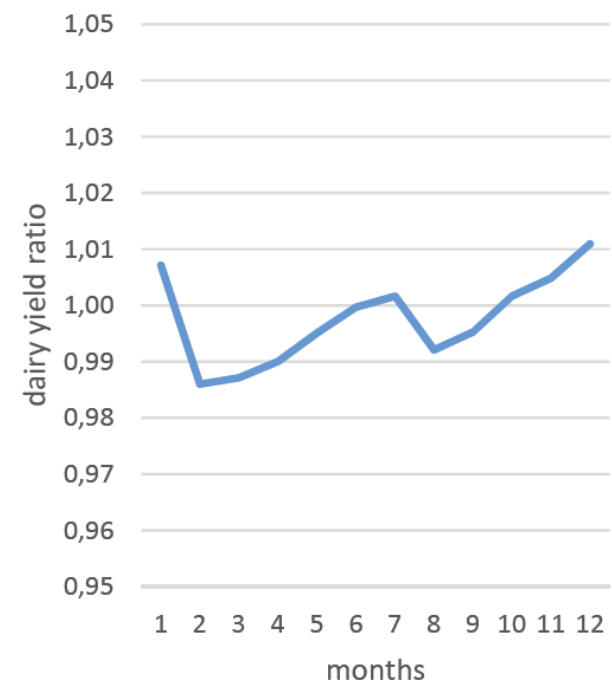

Figure 14: Dairy yield winter production, group A.

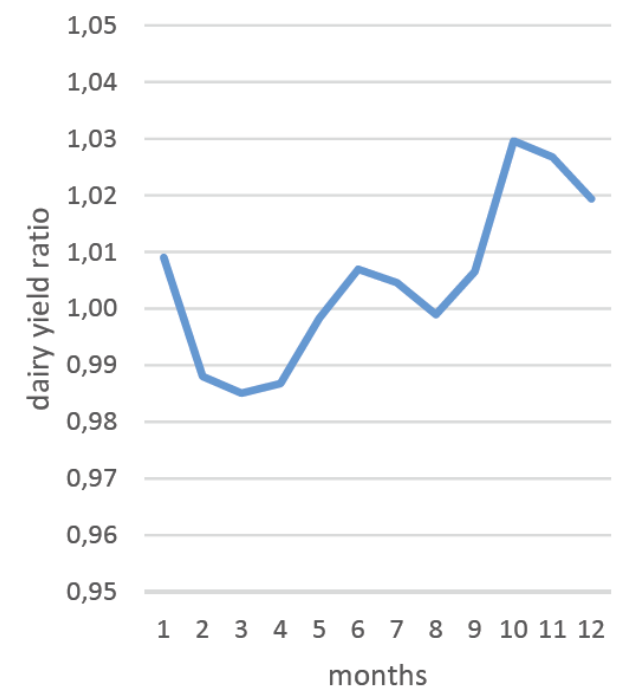

Figure 15: Dairy yield costant production, group B. 


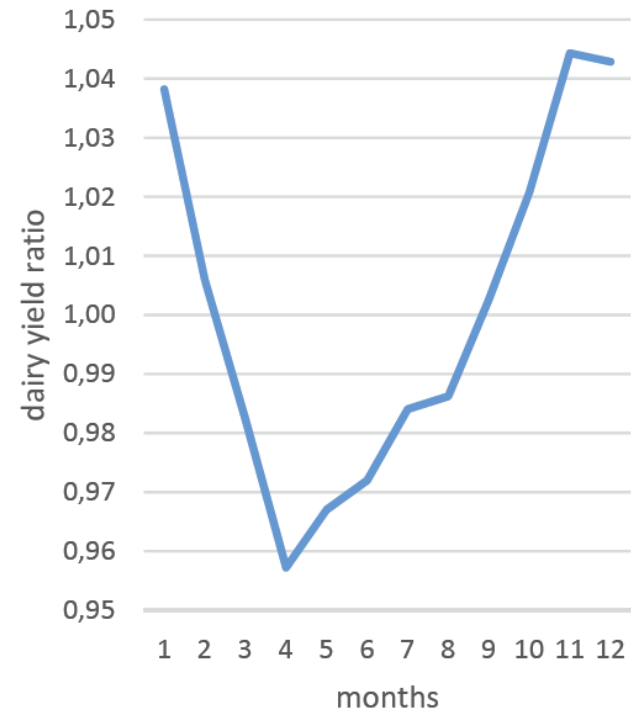

Figure 16: Dairy yield OBMS production, group C.

\section{Lactose Percentage}

The percentage of lactose is a parameter that changes less during lactation (high in the first 50 days after birth and progressively decreases when the length of the lactation increases). Figure 17 reveals that between June and August have the lowest values. In the $A$ and $B$ groups (Figures 18 and 19) the trend is similar and the lactose value shows a decrease in the hot season; it is possible that the cooling is not perfect. In group $\mathrm{C}$ the lactose value is equable. The phenomenon, that is observed in the C group, is likely, depends on the constant number of births from February to July and the cold weather after October, which does not adversely affect the lactose value.

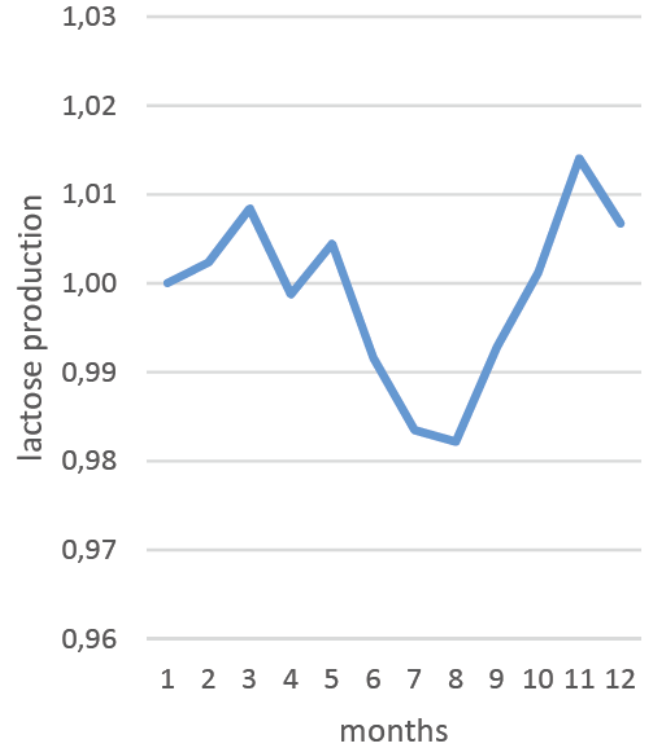

Figure 17: Lactose (total farms).

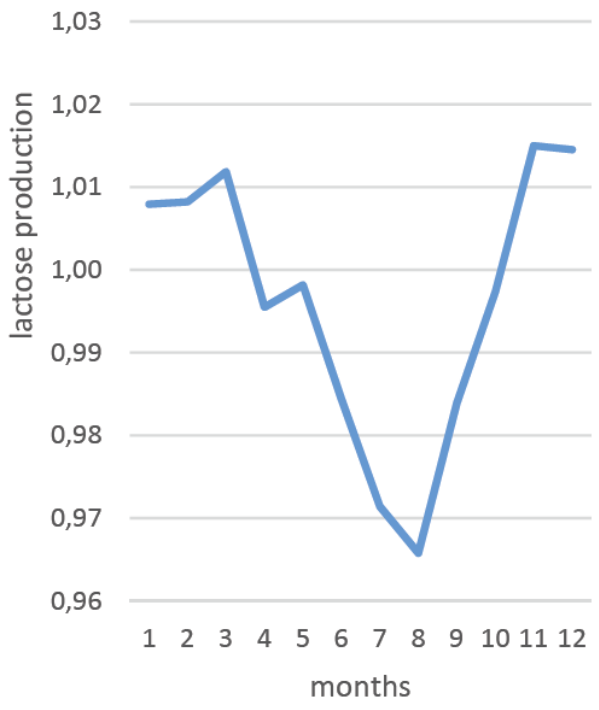

Figure 18: Lactose winter production, group A.

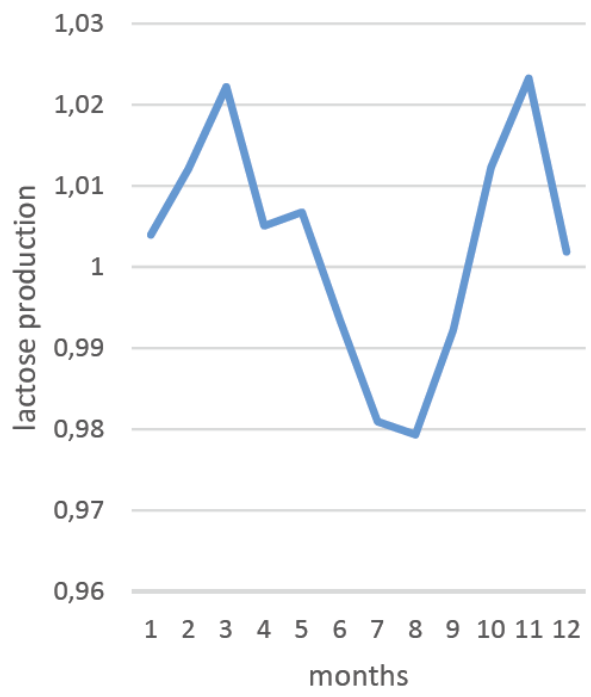

Figure 19: Lactose costant production, group B.

\section{Titratable Acidity $\left({ }^{\circ} \mathrm{SH}\right)$}

The trend of titratable acidity ( ${ }^{\circ} \mathrm{SH}$ ) is more or less constant with a high value in December and an increase between April and July. The above trend is similar in the buffaloes of the A and B group; in the above groups is possible to observe low value between August and September and between Jun and August in $A$ and $B$ group respectively. In the farms of the group $C$ (Figure 24), at contrary, we observe low value between June and September and in January, when the length of lactation is shorter.

\section{pH Values}

On average $\mathrm{pH}$ values tend to drop towards December-January and then rise again in February, it 
is clear to a lowering in July (Figure 25); in " $\mathrm{A}$ " group the $\mathrm{pH}$ value decreased between Jun and September (Figure 26). In B group (Figure 27), there is a slight lowering of $\mathrm{pH}$ values in the months of December and January. In $\mathrm{C}$ group of the OBMS production (Figure 28) shows the peak decrease in $\mathrm{pH}$ in the month of July. Evidently, the sudden lowering of $\mathrm{pH}$ in the July is probably due to hot weather. Between titratable acidity and $\mathrm{pH}$, value there is an inverse correlation. In the months corresponding to the concentration of calving, mostly in OBMS herds, there are SH increase, and a decrease in $\mathrm{pH}$ (Figures 21 and 25).

\section{1,03}

1,02

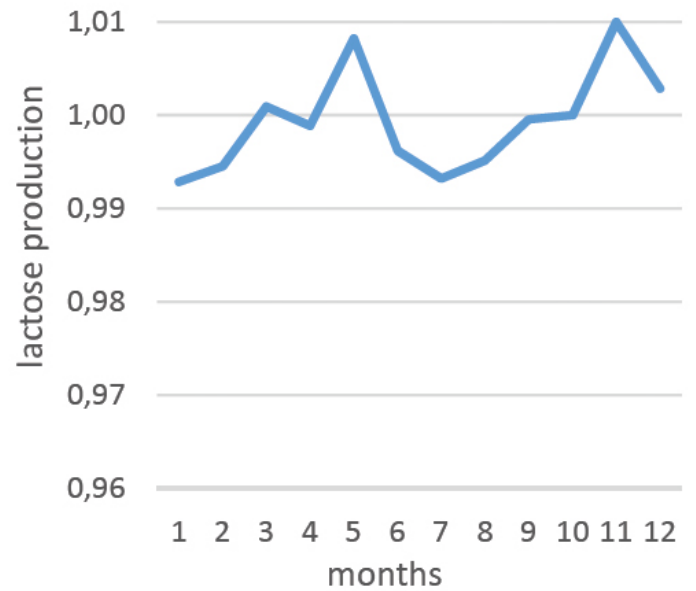

Figure 20: Lactose OBMS production, group B.

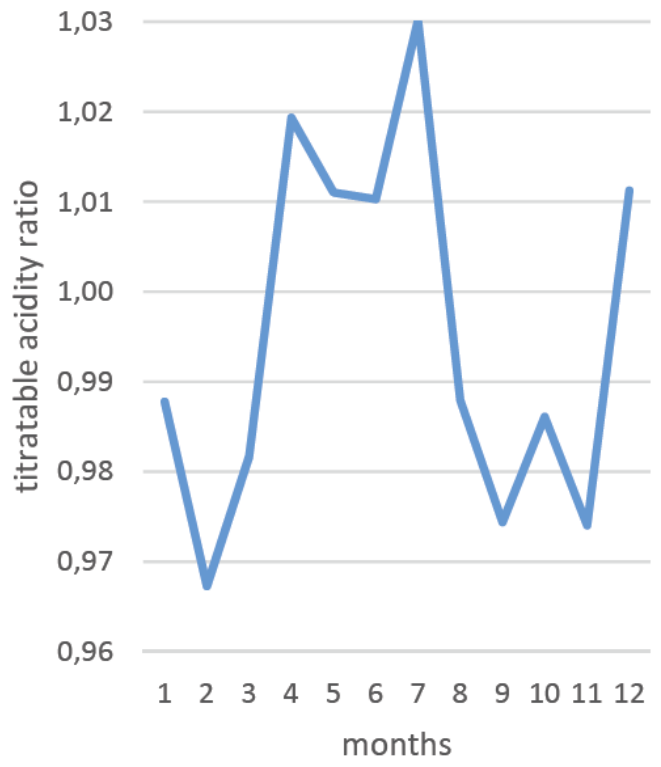

Figure 21: Titratable acidity (total farms).

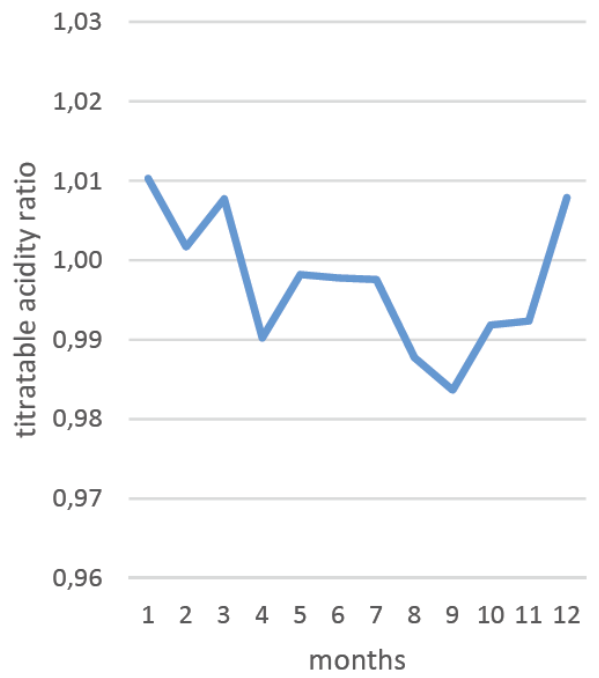

Figure 22: Titratable acidity winter production, group A.

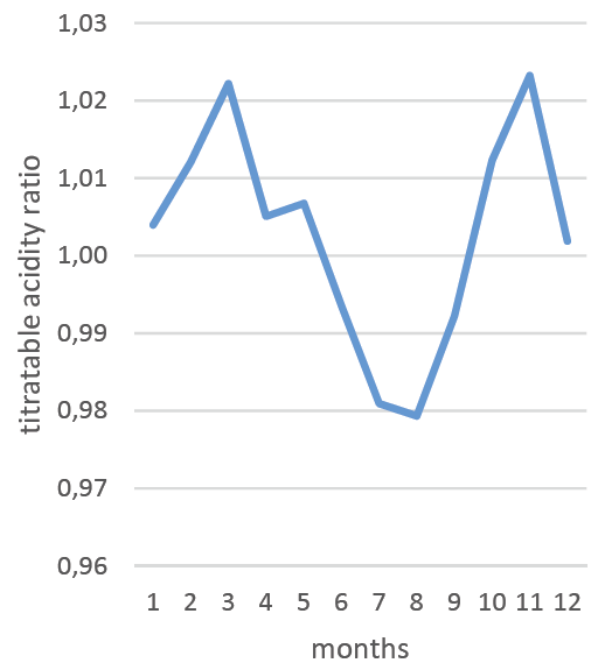

Figure 23: Titratable acidity costant production, group B.

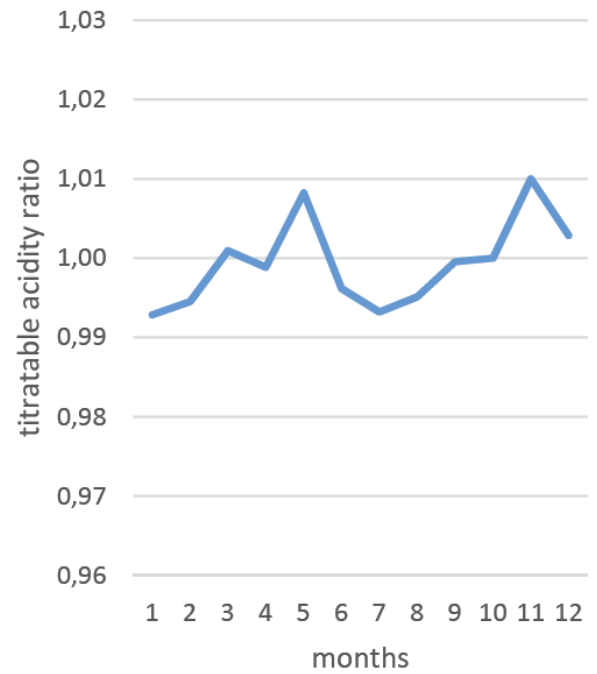

Figure 24: Titratable acidity OBMS production, group $\mathrm{C}$. 


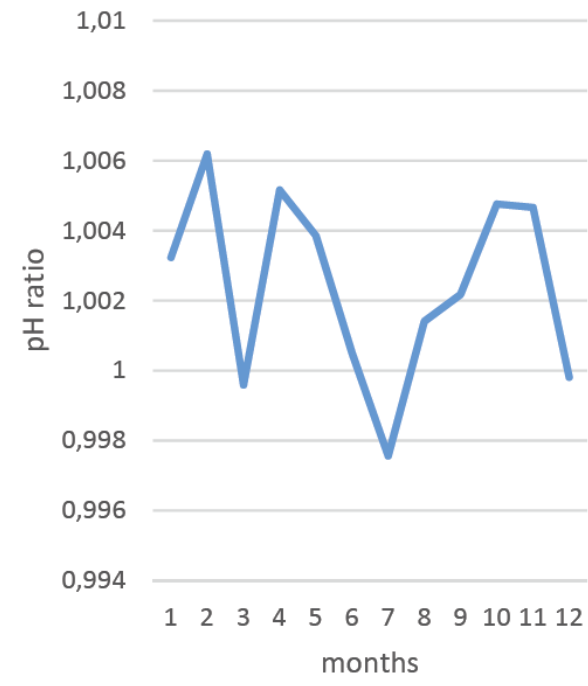

Figure 25: $\mathrm{pH}$ (total farms).

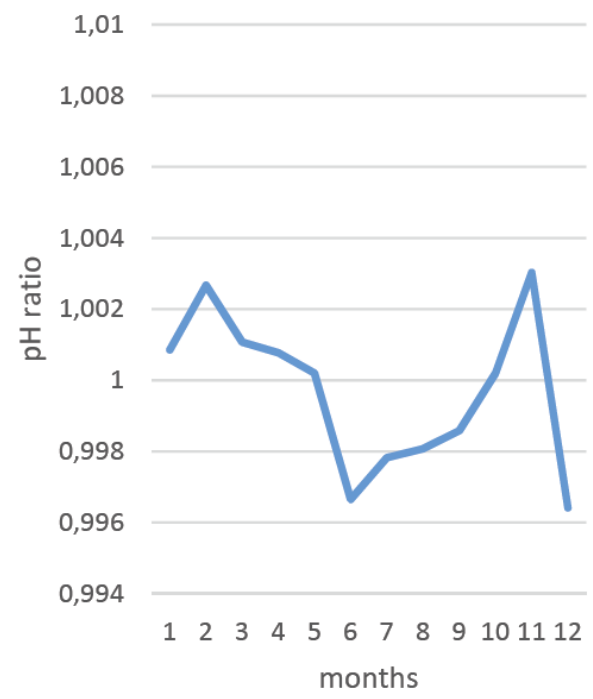

Figure 26: $\mathrm{pH}$ winter production, group $\mathrm{A}$.

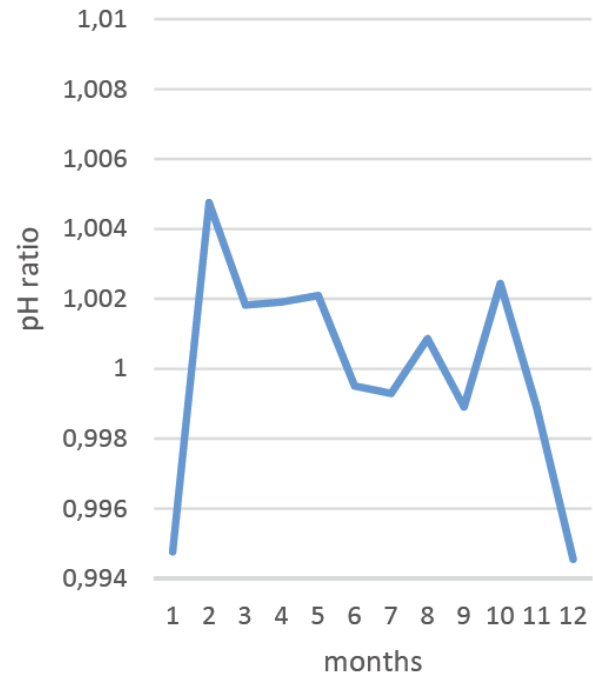

Figure 27: $\mathrm{pH}$ costant production, group $\mathrm{B}$.

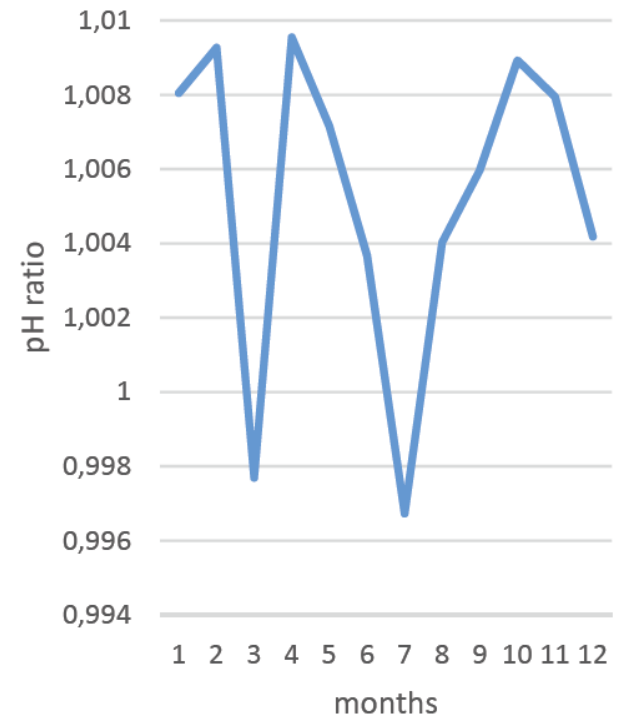

Figure 28: $\mathrm{pH}$ OBMS production, group $\mathrm{C}$.

\section{Production, Dairy Yield and Price of Milk}

If we compare the productions and the yields recorded in the three groups (Figures 2, 3, 4 and 14, $15,16)$ it is evident that in the months when the production is higher, the yield is lower. Normally, the milk is paid according to the season and the dairy yield. In particular, a summer price (April to September) and a winter price (October to March) are practiced rewarding or penalizing respectively the summer and winter milk. The real price is established on the milk evaluation with reference to the dairy yield average value $(25.6 \%)$ which corresponds to the theoretical price. Obviously if the dairy yield increases, also the price will be higher than the theoretical one, and vice versa. It follows that farms who work to produce "summer" milk, according to the higher market demand, see their remuneration penalized because when the production increases, the dairy yield lowers since buffaloes have calved not long before. The type of remuneration $\mathrm{A}$, currently in use, $(€ / \mathrm{kg} 1.15$ and 1.4 respectively in winter and in summer, the same for the three groups) provides higher price than $1 \%$ and $2.9 \%$ respectively of group $A$ and $B$ which is insufficient to cover the higher costs $(+20 \%)$ of OBMS technique. These costs are covered, in fact, if the summer milk produced is paid $€ / \mathrm{kg} 1.25,1.39$ and 1.65, respectively in farms of the group $B, A$ and $C$. The type of remuneration $B$ indicates that average OBMS farms remuneration is $20.7 \%$ higher $(€ / \mathrm{kg} 1.44 / 1.196)$ and $15.8 \%$ higher $(€ / \mathrm{kg} 1.44 / 1,243)$ respectively, of that of the farms with winter (A group) or constant (B group) production. With $B$ remuneration, the breeders who adopt OBMS would not be penalized and would be 
Table 1: Production (kg) of the Winter Semester (January-March + October-December) and Summer Semester (AprilSeptember), $€ /$ kg Theoretical (Theo), $€ /$ kg Real, $€ /$ kg Paid in Function of the Criteria A or B.

\begin{tabular}{|c|c|c|c|c|c|c|c|c|}
\hline Tipe of paid & & & \multicolumn{3}{|c|}{ A } & \multicolumn{3}{|c|}{ B } \\
\hline Group/semester & & & theo & real & & theo & real & \\
\hline Constant prod. & $\mathrm{Kg} /$ semester & $\%$ & $€ / \mathrm{kg}$ & $€ / \mathrm{kg}$ & $€ /$ semester & $€ / \mathrm{kg}$ & $€ / \mathrm{kg}$ & $€ /$ semester \\
\hline winter & 2.460 .638 & 48,33 & 1,15 & 1,13 & 2.788 .098 & 1,15 & 1,13 & 2.788 .098 \\
\hline summer & 2.630 .717 & 51,67 & 1,40 & 1,36 & 3.581 .158 & 1,39 & 1,35 & 3.555 .578 \\
\hline total & 5.091 .355 & & 1,27 & 1,25 & 6.369 .256 & 1,27 & 1,24 & 6.343 .676 \\
\hline Winter prod. & $\mathrm{Kg} /$ semester & $\%$ & $€ / \mathrm{kg}$ & $€ / \mathrm{kg}$ & $€ /$ semester & $€ / \mathrm{kg}$ & $€ / \mathrm{kg}$ & $€ /$ semester \\
\hline winter & 2.354 .646 & 51,40 & 1,15 & 1,15 & 2.704 .850 & 1,15 & 1,15 & 2.704 .850 \\
\hline summer & 2.226 .326 & 48,60 & 1,40 & 1,39 & 3.101 .822 & 1,25 & 1,24 & 2.769 .484 \\
\hline total & 4.580 .972 & & 1,27 & 1,27 & 5.806 .672 & 1,20 & 1,19 & 5.474 .334 \\
\hline Deseasonalisation & $\mathrm{Kg} /$ semester & $\%$ & $€ / \mathrm{kg}$ & $€ / \mathrm{kg}$ & $€ /$ semester & $€ / \mathrm{kg}$ & $€ / \mathrm{kg}$ & $€ /$ semester \\
\hline winter & 4.457 .316 & 41,81 & 1,15 & 1,18 & 5.269 .920 & 1,15 & 1,18 & 5.269 .920 \\
\hline summer & 6.203 .070 & 58,19 & 1,40 & 1,38 & 8.577 .334 & 1,65 & 1,63 & 10.109 .001 \\
\hline total & 10.660 .386 & & 1,27 & 1,28 & 13.847 .254 & 1,40 & 1,44 & 15.378 .921 \\
\hline
\end{tabular}

encouraged to adopt the technology and those who do not adopt it would be stimulated to adopt it (Table 1).

\section{DISCUSSION AND CONCLUSIONS}

The milk's flow in the dairy was characterized by a steady increase between January and August and by a progressive decline between September and December, in accordance with the market demand. Despite this trend, $35 \%$ and $17 \%$ respectively of the farms presented winter production and a generally constant production during the year. The average amount daily milk production of the three groups of farms was not different. The described trend influenced the chemical composition of the milk. Especially during the months when there has been a steady increase in production as a consequence of the grouping of the calving there was a lower percentage of fat, protein and of course of the yield dairy. At the same time (June July) there was an increase of titratable acidity and of course a decrease in $\mathrm{pH}$. As in January, the percentage of lipid decreased until April and then increased until November, then it decreased again in December when the calving period started. This trend is more amplified in the farms of the group OBMS, while in the other two groups lipid deflection is less evident for the most constant calving. The trend of the protein percentage and lipid percentage is congruent with the dairy yield for the interconnections that bind these three elements. In the three groups, the trends of the lactose's percentage show a decrease in the hot season; it is possible that the cooling of the samples was not perfect. Values of titratable acidity, although normal, are more or less constant with an increase in July and December. In the group "A" and " $B$ ", the highest values are recorded in February, November and December when the length of lactation is higher and the climate is cold. In this period, buffaloes as they are animals that come from the tropics often burn the fat reserves for thermoregulation and this process determines hyperketonemia with increased levels of $\mathrm{SH}$ values. Usually $\mathrm{pH}$ values tend to lower in December-January and then rise again in February; it is evident a considerable drop in July, especially in OBMS herds likely due to the concentration of the calving. Between the titratable acidity and the $\mathrm{PH}$ value there is a clear inverse correlation. In the months corresponding to the concentration of the calving, especially in the OBMS herds, there was an increase in $\mathrm{SH}$ values and a decrease in the $\mathrm{PH}$. This trend depends, as already noticed for the lactose, from the ambient temperature. Thanks to the evolution of the chemical composition and yield dairy along the year, it has been possible to verify that the milk remuneration according to the season (summer price and winter price) and to the yield, but independent from the seasonal production of the herd, does not allow to satisfactorily remunerate farms that adopting OBMS meet the market needs. The breeders see their remuneration penalized because when the production increases, the dairy yield lowers since buffaloes in these herds are close to calving. To avoid this it is necessary that the remuneration of "summer" milk is $€$ / $\mathrm{kg} 1.25,1.39$ and 1.65 respectively for farms 
characterized by winter production, by constant production, and OBMS production. We suggest that the remuneration of "summer" milk of OBMS farms is $32 \%$ and $19 \%$ higher than milk from respectively winter production farms or constant production farms. This type of remuneration guarantees an annual average price for the OBMS farms which is $20.7 \%$ and $15.8 \%$ higher than the price of farms with winter production or constant production. With this remuneration the breeder who adopts OBMS would not be penalized and would continue to adopt the technique while those who did not, would be stimulated to adopt it. The seasonal nature of the buffalo in the past caused a greater supply of milk in the period when the request was lower and vice versa. The use of curds or frozen milk was considered the only solution also because the remuneration practiced on "summer" milk did not induce all breeders to seasonally adjust the herd. The seasonal nature of that species increased the supply of milk in the period, when the demand was lower and vice versa. The use of curds or frozen milk was considered the only solution because the remuneration practiced on "summer" milk did not induce the breeders to seasonally adjust the herd. The dairy workers on one hand ask for "summer milk" on the other try to stock up on "winter" milk to meet the high demand of the product and to make the so-called promotions in June and July. Even the Legislator, generally on the producers' side, allows all this. In my opinion, the promotion of fresh products should be forbidden by law: it is impossible that a dairy buffalo produces $20-30 \%$ more milk within a few days.

\section{REFERENCES}

[1] Napolano R, Potena A, lovane G, Coletta A, Campanile G, Neglia G, Zicarelli L. Relationships between Italian Mediterranean Buffalo milk compounds - Proceedings of the VIII World Buffalo Congress, Caserta - Italy. Ital J Anim Sci 2007; 6.

https://doi.org/10.4081/ijas.2007.s2.1088

[2] Potena A, De Filippo C, Bove D, Cocca T, Haubner T, Zicarelli L. Resa alla caseificazione e parametri reologici del latte bufalino: risultati preliminari su latti individuali - I Congr. Naz. sull'Allevamento del bufalo, Eboli 2001; 236-240.

[3] Zicarelli L, Neglia G, Napolano R, Di Rubbo M, Caso C, Gasparrini B, Di Palo R. Correction of the ratio between real cheese yield at 28 hours and protein according to chemical composition of buffalo milk - Proceedings of the VIII World Buffalo Congress, Caserta - Italy 2007. https://doi.org/10.4081/ijas.2007.s2.1108

[4] Zicarelli L. Nutrition in dairy buffaloes (Alimentazione della bufala da latte) Bubalus bubalis, numero speciale 2001b; pag. 1, 66 .

[5] Zicarelli L. Reproductive seasonality in buffalo; 3th international course of biotechnology in buffalo reproduction, Napoli 6-10-97, suppl. bubalus bubalis 1997a; 29-52.

[6] Zicarelli L. news on buffalo cow reproduction, proc. 5th world buffalo congress, Caserta 13-16-10, 1997b; 124-141.

[7] Zicarelli L. Out-of-breding-season mating technique in buffalos (OBMSO). Perspectives of buffalo husbandry in Brazil and Latin America. Editores Prof. H. Tionhati, Prof. V.H. Barnabe, Prof. P.S. Baruselli, Funep, Jabuticabal 1999a; pag. 179 - 202

[8] Intrieri F, Barbieri V, de Franciscis G, Cavalieri A, Altiero V. Proposta di un modello matematico per il pagamento del latte di bufala secondo qualità. Atti SISVet 1986; 40: 754756.

[9] Altiero V, Moio L, Addeo F. Previsione della resa in mozzarella sulla base del contenuto in grasso e proteine del latte di bufala. Scienza e tecnica lattiero-casearia 1989; 40: 425-433. 